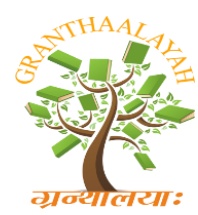

INTERNATIONAL JOURNAL OF RESEARCH GRANTHAALAYAH

A knowledge Repository

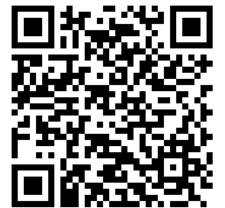

Social

\title{
A STUDY OF ENGLISH COMMUNICATION PROBLEM BETWEEN NON-THAI AND THAI CO-WORKERS IN LUTHERAN CHURCH IN MUKDAHAN AND UBON RATCHATHANI AREAS
}

\author{
Supornnee Jampa ${ }^{1}$, Nutprapha K. Dennis ${ }^{* 2}$ \\ $1,{ }^{*}$ Ubon Ratchathani Rajabhat University, THAILAND
}

\begin{abstract}
This study investigated English communication problem between non-Thai and Thai coworkers in Lutheran church. The study focused on the problems of English listening and speaking skills. The questionnaires were used to collect the data. The data analysis was presented in descriptive statistic. The research findings: 40 Thais and 13 non-Thai co-workers were more female than male in respondents of the study. Most of the Thai co-workers have previously graduated with a bachelor's degree. There were $38.46 \%$ of the non-Thais have previously graduated with bachelor's degree. There were $76.92 \%$ of the non-Thais come from Norway and they do not use English as a first language. Most of non-Thai respondents used Thai language communicated with Thai co-workers. The English communication problems exist between Thai and non-Thai co-workers at their work. The most difficult English skill for Thai co-workers was speaking whereas for non-Thais, it was the listening skill in communication. All of Thai co-workers often have problems in both listening and speaking skills. The major problems in communication were accent/pronunciation, using correct grammar and using appropriate words. Whereas foreigners communicated with Thai coworkers, there were major problems with understanding Thai co-workers' accent/pronunciation of English.
\end{abstract}

Keywords:

English communication problem, listening skill, speaking skill.

Cite This Article: Supornnee Jampa, and Nutprapha K. Dennis, “A STUDY OF ENGLISH COMMUNICATION PROBLEM BETWEEN NON-THAI AND THAI CO-WORKERS IN LUTHERAN CHURCH IN MUKDAHAN AND UBON RATCHATHANI AREAS" International Journal of Research - Granthaalayah, Vol. 4, No. 1 (2016): 131-137.

\section{INTRODUCTION}

In 2015, Thailand will be part of ASEAN Community. English language is central for communication such as political, economic, social, educational, cultural, and for tourism. Nowadays, English in Thailand has been accepted as an international language. Thai people learn English through early childhood in school until university and some of them continue to 
learn in private courses. The English language is important for roles in the daily life. In addition, knowing English gives a chance to get a good job, and is important to understand other cultures. English is the dominant language and it has become almost a necessity for people, if they want to work in global workplaces. Research has determined that business between countries is conducted most frequently in English. Many factors demonstrate the importance of English such as English is an international language used in education, business, and social and political contexts, as Thitthongkam (2011) stated in his research. The learners need to improve their ability of English, especially speaking and listening skills, to compete with other nations. People need these skills in order to communicate with foreigners both outside and inside their country. English communication has an important role for multinational corporations and industries who are investing in Asia and for Thai people who want to work with them as well. When people begin interaction with other people in society, communication is inevitable; the ability to communicate in English is needed as an essential skill. It is not easy for people who do not use English as a first language or second language to communicate with foreigners.

At present, many foreign evangelists or missionaries come to Thailand to disseminate the word of God. They are teaching Christians abroad. The foreign evangelists have to use English language to communicate with the local people. Speaking a language is especially difficult for foreign language learners because effective oral communication requires the ability to use the language appropriately in social interactions, as Wanthanasut (2008) stated in her master's thesis. The English communication is very important in most peoples' work. Thai people, who are working in the Churches use English more frequently to communicate with the foreign evangelists. The problems could occur from the lack of language skills such as using inappropriate language and expressions. The partnership between missionaries and Thai Christian leaders has not always been easy. In his master's thesis, Dao-Ming Chang (2011) found that the Thais likewise have both positive and negative thoughts regarding partnership with missionaries. Thai co-workers and missionaries say that they need English language teaching because English is used as the medium of communication. In his doctoral thesis Mejudhon (1997) refers to the number of foreign missionaries as strictly controlled, at that time there were approximately 1,000 missionaries and sixty Christian organizations in Thailand.

The problems from the lack of language skills may cause misunderstandings in communication between Thai co-workers and foreigners because they have languages differences. Moreover, it may even lead to the failure in their work. The ability to communication well can enhance success in their work. In this study the researcher observed that officers, workers, and students were trying to find a place to learn English such as an institute of English Language Teaching and English courses. Some companies and organizations have focused on the importance of the English language. They have tried arranging English training, English seminars or English courses to employees. These things helped them to improve their English skills; especially communication skill that is an important skill in work. This study aims to explore the problems in English communication which are barriers or affecting the communication between Thai coworkers and foreign evangelists in Lutheran Church in Thailand.

Statement of the Problem: English communication is important for Thai co-workers who are working with foreigners especially, Thai co-workers who communicate regularly with foreigners in the church. They may have problems in their conversations. Thai co-workers try to learn how 
to communicate with foreigners but they still do not achieve effective communication all the time. There are many factors that affect success. This study identifies the problems in English communication affecting the work of the Thai co-workers with non-Thai co-workers and provides useful information for finding the effective way to develop the communication skills of the Thai co-workers.

Purpose of the Study: To investigate the English communication problems between non-Thai and Thai co-workers in the Lutheran church in Mukdahan and Ubon Ratchathani areas.

Research Question: What English communication problems occur between non-Thai and Thai co-workers in Lutheran church in Mukdahan and Ubon Ratchathani areas?

Significance of the study: This study aimed to investigate the English communication problems between non-Thai and Thai co-workers. Therefore, the result and suggestions of this study may help the Thai co-workers to develop their communication skills and can also be useful for foreigners to find an effective way to communicate with local Thai co-workers. This can lead to increasing ability of workers. In addition, the information can be a guideline to design English course in evangelists' office or church in Thailand.

Scope and Limitation of the Study: This research was created to survey the English communication problems. The study focuses only on listening and speaking skills. The subjects in this study were non-Thai and Thai co-workers who were working at Lutheran Church in Mukdahan and Ubon Ratchathani area.

\section{RESEARCH METHODOLOGY}

This study investigated the communication problems of Thai co-workers while working with non-Thai co-workers using English as a medium. This section contains information about subject of the study, research design, research instruments, construction and efficiency of the instrument, data collection, and data analysis.

Subjects of the Study: The subjects of this study were 40 Thai co-workers and 13 non-Thai coworkers who are working in 8 Lutheran churches in Mukdahan and Ubon Ratchathani. Thai coworkers in this study were officers, volunteers, and evangelists. Non-Thai co-workers in this study were Norwegian teachers, volunteers and evangelists or missionaries.

The 8 Lutheran churches in Ubon Ratchathani and Mukdahan are as follows:1) Banpran Lutheran Congregation 2) Good News Ubon Ratchatani Lutheran Congregation 3) Phibun Mangsahan Lutheran Congregation 4) Fahuan Lutheran Congregation 5) Tungpraporn Khoknoi Lutheran Congregation 6) Ruamprakuhn Nam Thaeng Lutheran Congregation

7) Nong Nok Ta Lutheran Congregation 8) Mukdahan Lutheran Congregation

Research Design: This study was a survey research which the researcher conducted a full literature review in search of relevant information toward English communication in a workplace. Questionnaires with Thai and English were used to collect the data which distributed to 8 Lutheran church in Mukdaharn and Ubon Ratchathani both non-Thailand and Thai coworkers. 
Research Instrument: Research instrument to collect the data in this study was a questionnaire. It was distributed to 40 Thai co-workers and 13 non-Thai co-workers. Two questionnaires were designed; one was for Thai co-workers and the other was for non-Thai co-workers. The questionnaire were written in English and Thai and designed according to the purpose of this study.

Construction and Efficiency of the instrument: The questionnaires in this study were constructed according to purpose of this study. The questionnaires for each group were the same: the first part of the questionnaires was to collect demographic information including, age, background of education, length of time working, and whether any English courses had been taken, the second part of the questionnaires focused on the problems of English for communication. An expert checked the efficiency of the instrument. The questionnaires were revised following advice from Thai and foreign experts working in the Norwegian missionaries' organization.

Data Collection and Analysis: The researcher proceeded to collect data from the 40 Thai coworkers and 13 non-Thai co-workers from 8 Lutheran churches in Mukdahan and Ubon Ratchathani. The data analysis statistics used were mean, frequency, standard deviation (SD) and percentages. Data was analyzed using a statistical computer program (SPSS). Descriptive statistics are used to present the result of the study.

\section{RESULTS AND DISCUSSIONS}

In this part the researcher will discuss the results of the data analysis and findings as presented above in light of the research question. The research question was "What are English communication problems of non-Thai and Thai co-workers at Lutheran church in Mukdahan and Ubon Ratchathani area?" In the research the subjects were asked about what communication skill that is most difficult. When reviewing the data concerning problems in English communication, the results indicated that the most difficult English communication skill for the majority of the Thai co-workers were the speaking skill, whereas non-Thai co-workers indicated that the listening skill was the most difficult skill. Interestingly, only one subject in each group indicated that reading skill was the most difficult English communication skill. This shows that the Thai co-workers and non-Thais have different communication problems, when communicating to each other in English. The Thai-workers have difficulties in speaking, which is a productive skill, while non-Thais have difficulties in listening, which is a receptive skill. Foreigners might have difficulties in listening to Thai co-workers that find speaking difficult. This is similar to the results in the other studies. Pakeesheep (1999) reported the study of the problem in English communication between Electricity Generating Authority of Thailand's engineers and foreign consulting engineers. The results revealed that the culture difference and communication skills; especially speaking and listening, was the major communication problems.

In this research, the subjects were asked about how often they have problems in speaking skill. When reviewing the data concerning problem in speaking skill, the results indicated that the Thai and non-Thai co-workers had English communication problem in speaking and listening skills. The result shows that most of the Thai co-workers often had problems in speaking communication skill, whereas non-Thais rarely had problem in speaking skill. The Thai co- 
workers often had problem in use correct grammar and problem in pronounce correctly, whereas non-Thais only sometimes had the same problems. Non-Thai co-workers rarely had problem in introducing oneself and greeting and problem using appropriate words and engaging in general English conversation to create good relationship with Thai, while as the Thai co-workers often had problem in engaging in general English conversation to create a good relationship with nonThai co-workers and problem using appropriate words and sometimes problem in introducing oneself and greeting. This data shows that using English by these two different groups to introduce greet and create good relationship might be difficult. This might be one reason why many of the non-Thai co-workers $(53.85 \%)$, choose to use Thai to communicate with Thai coworkers. Introducing, greeting and creating good relationships are essential when working together.

In this research the subjects were asked about how often they have problems in listening skill. When reviewing the data concerning problem in listening skill, the results indicated that Thai coworkers often had problems in listening communication skill, while as non-Thai co-workers sometimes had the same problem. The non-Thais only sometimes had, but Thai co-workers often had, problem in listening for main idea of conversation, problem in listening to word or English vocabulary and problem in listening to non-Thais' English accent. This might be because most of the non-Thai subjects in this research come from Norway, only a minority (15.38\%), come from America. The non-Thais from Norway have a distinct English accent, and English is not their first language. But the researcher have no data concerning whether the Thai co-workers have less problem in listening to non-Thais', whose English is first language, English accent. Both Thai and non-Thai co-workers in the research reported to sometimes have problem in understanding to sentences.

The result of this study indicates that the Thai co-workers often had problems in speaking and listening communication skills more than the non-Thai co-workers. This is part of an answer to the question raised about what are the most difficult English communication problems. In this research the subjects were asked about to what extent they have problem in the workplace when communicating with each other. When reviewing the data concerning problem in workplace the results indicated that Thai and non-Thai co-workers had some communication problem in their workplace. But the Thai co-workers reported to have more problems than the non-Thais that only had slight problem communicating in their workplace. The result shows that Thai co-workers had problem in using English. They cannot understand accents, misunderstanding due to grammatical error, they could not use appropriate words and they were lack of communication skills. Non-Thai co-workers only had problem in understanding accents when they had encounter Thai co-workers in their workplace.

The research found that both Thai and non-Thai co-workers had similar problems in not understanding accents. This is consistent with difficulties in speaking and listening. This is similar to the results in Netsuwan (2008) found that communication problems between information staff and foreign passengers, at Suwannaphumi airport, were incorrect grammatical sentences, mispronouncing the words, inappropriate words choice or vocabularies choice, and low speaking volume. Furthermore the results of this study indicated that Thai co-workers had more problems in communicating than non-Thai co-workers in the workplace. 


\section{CONCLUSIONS \& RECOMMENDATIONS}

This study investigated English communication problems between non-Thai and Thai coworkers at Lutheran church. . The research question was "What are English communication problems of foreigners and Thai co-workers at Lutheran church in Mukdahan and Ubon Ratchathani area?" Questionnaires were distributed to 40 Thai co-workers and 13 non-Thai coworkers in 8 Lutheran churches in Mukdahan and Ubon Ratchathani. There were 40 Thai coworkers, 26 females and 14 males, and 13 non-Thai co-workers, 7 females and 6 males, were the respondents of the study. There were 10 non-Thai co-workers came from Norway, 2 came from America and 1 came from the Philippines. There were 7 non-Thai co-workers used Thai language to communicate and 6 of them used English language to communicate with Thai coworkers.

The results from this study indicated that speaking and listening skills are the most difficult skills and major communication problem in English between non-Thai and Thai co-workers that were respondents in this study. For the Thai co-workers, speaking skill was the most difficult skill, while for the non-Thai, listening skill was the most difficult skill. This shows that non-Thai and Thai co-workers have different communication problems, when communicating to each other in English. But the research showed that most of the Thai co-workers often had problems in speaking communication skill, whereas non-Thai rarely had problem in speaking skill. The data in this study showed that using English by these two different groups to introduce, greet and create good relationship might be difficult. This might be one reason why many of the non-Thai choose to use Thai to communicate with Thai co-workers. When reviewing the data concerning problem in listening skill, the results indicated that Thai co-workers often had problems in listening communication skill, while non-Thai sometimes had the same problem. The result of this study indicates that the Thai co-workers often had problems in speaking and listening communication skills more than the non-Thai group. This is the part of an answer to the question raised about what are the most difficult English communication problems. When reviewing the data concerning problem in workplace the results indicated that non-Thai and Thai co-workers had some communication problem in their workplace. But the Thai co-workers reported to have more problems than the non-Thai, that only had slight problem communicating in their workplace. Non-Thai co-workers only had problem in understanding accents when they had encounter Thai co-workers in their workplace. The research found that both Thai and non-Thai co-workers had similar problems about misunderstanding accents. This is consistent with difficulties in speaking and listening. The results of this study indicate that Thai co-workers had more problems in communicating than non-Thai co-workers in the workplace.

Communicating using English can be important for both the Thai and non-Thai co-workers as they have different first languages. English is their shared language. Problems and lack of English skills may cause communication problems.

Recommendations: The researcher has recommendations for further study as follow: First, the numbers of respondents in this study was few, further study should involve more participants in other churches. Second, further studies may focus on the communication problems of Thai working with non-Thai workers in different organizations. Third, the results of this study can be a guideline to design English courses that are appropriate for developing English skills within the 
Lutheran church. This study shows some of the communication problems that can occur when non-Thai and Thai co-workers use English as a medium for communication in the workplace. The researcher would suggest an English course design that focuses specially on speaking and listening skills.

\section{ACKNOWLEDGEMENTS}

This independent study would not have been completed without the generous help from many people. First of all, I would like to express my sincerest thanks and gratitude to my advisor, Nootprapa Kongphet Dennis, Ph.D. for her valuable suggestions and creative criticism throughout the course of the study. My grateful thanks also go to Assistant Professor Wutti Leenam of the instructors at the Faculty of Humanities and Social Sciences of Ubon Ratchathani Rajabhat University and Naruemon Duangsang, Ph.D. the external examiner. My thanks also go to the Norwegian missionaries, Norwegian volunteers and the Thai co-worker at Lutheran churches at Mukdahan and Ubon Ratchathanii for their kind assistance and sincere encouragement. Finally, I would like to express my most special thanks to the members of my family who have been the source of my inspiration in my pursuit of a higher educational degree.

\section{REFERENCES}

[1] Dao-Ming Chang, D. Forming Effective partnerships with Thai Christian leaders in church planning. Unpublished master's research paper, Master thesis, School of Intercultural Studies. (Online) 2011 (cited 8 May 2014). Retrieved from http://www.thailis/journal/problem communication.pdf

[2] Mejudhon N. A New Approach to Christian witness to the Thai people. (Online) 1997 (cited 9 July 2014). Retrieved from: http://thaimissions.info/gsdl/collect/thaimiss/index/assoc/HASHee02.dir/doc.pdf

[3] Netsuwan S. A Study of English Communication Problems Between Information Staff And Foreign Passengers at Suvarnnabhumi Airport. Master thesis, Kasetsart University, 2008.

[4] Pakeesheep N. The study of the problem in English communication between Electricity Generating Authority of Thailand's engineers and foreign consulting engineers. (Online) 1999. Retrieved from

http://www.litu.tu.ac.th/journal/download/pdf/LITU_Graduate_Conference_Proceedings _2013.pdf

[5] Thitthongkam T. The Roles of Foreign Language in Business Administration School of Management. (Online) 2011 (cited 5 June 2014). Retrieved from http://www.thailis/journal/problem communication.pdf

[6] Wanthanasut L. The Problems of English Speaking of Mattayom Suksa 1 Students At Phosai Pittayakarn School, Ubon Ratchathani Educational Service Area 2. Master's Independent Study. Ubon Ratchathani Rajabhat University, 2008: 12. 